\title{
OPTIMIZATION OF MARKETING INFORMATION SYSTEM FOR CLOTHING PRODUCTION IN BANDUNG CITY, INDONESIA
}

\author{
Tri Indra Wijaksana \\ Mahir Pradana
}

Telkom University, Bandung, Indonesia

Clothing business is one of the fashion businesses that has been developing rapidly in the last couple decades. Shopping places like distro (distribution store), as a place selling clothes, are now located almost at every point of downtown Bandung. In order to survive under such a tight competition, a company must develop appropriate marketing strategies and try to meet the needs and desires of consumers by generating products that have a higher value as compared to competitors. This study aims to obtain empirical evidence on the use of marketing information systems to improve product development, and when/whether companies should further intensify their programs of marketing intelligence or information collection from the outside so that to be aware of competitor's superiority. The authors also explain the need to carry out in-depth marketing research on both products and consumer needs as well as on the growing market trends. These are the prerequisites for survival in the industrial world today.

Keywords: E-Commerce, User Satisfaction, Consumer Behavior.

\section{Introduction}

Development of businesses in Indonesia, especially when it comes to the clothing subsector, demonstrates the presence of extremely tight competition. This can be seen from the rise of various boutiques, factory outlets, distros and other clothing stores that have sprung up in all major cities in Indonesia, including Bandung, a city known to many as the Paris of Java.

Bandung which is the center of the clothing industry, every weekend is flooded with hundreds of visitors from outside the city, especially from the capital city of Jakarta, who came to places selling clothing to meet their fashion needs.

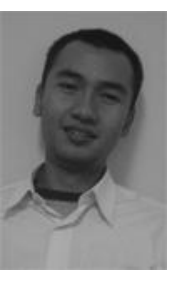

Tri Indra Wijaksana

The Faculty of Communication and Business, Telkom University, Indonesia

Research interests: marketing strategies, marketing communications, customers behavior

E-mail: triindrawijaksana@telkomuniversity.ac.id

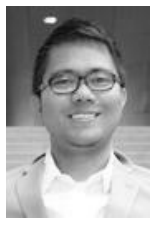

Mahir Pradana

The Faculty of Communication and Business, Telkom University, Indonesia

Research interests: marketing strategies, marketing communications, customers behavior

E-mail: mahirpradana@telkomuniversity.ac.id 


\section{OPTIMIZATION OF MARKETING INFORMATION SYSTEM}

This phenomenon makes clothing entrepreneurs strive to provide the widest variety of their products, in order to meet the fashion trends that are so dynamic that customer needs are met. Besides that, followers and/or competitors are popping up everywhere and daily because they see the promising market potential, and this makes the competition in this business sector even tighter. Therefore, every company operating in this sector is required to be able to increase all its activities in order to compete and maintain own viability so that the company's goals can be achieved.

Many clothing and distro companies exist in the city of Bandung in addition to the outlets of the already famous clothing brands like Rumah Mode, Heritage, Blossom, and many others. All these clothing and distro companies cover a wide range of products, and one of its main products is t-shirts with various attributes offered. Since this marke offers a huge choice of them, a truly competitive enterprise is expected to provide stimulants so that consumers decide to purchase specifically from them. Therefore, clothing and distro companies always strive to improve product quality, innovate products by providing various new and original features. Generally speaking, they strive to provide unique and varied designs in order to compete with their trade rivals.

To overcome all these problems research needs to be carried out in close connection to marketing information systems on clothing and distro product development in Bandung and Java overall. Starting from the description above, the authors intend to conduct a research which preliminary got the following title: "Utilization of Marketing Information System to Increase the Development Of Products by One Clothing Company in Bandung". follows:

Basing on the above background, the authors identify the central problem here as

How to use marketing information system so that to maximize the business efficiency of a clothing company in Bandung? How product development is done by one of the numerous clothing companies in Bandung? and finally, How much influence does the utilization of marketing information system have on product development at a Bandung clothing company in question?

\section{Literature Review}

In everyday life people cannot be separated from marketing activities because marketing is part of human life that helps humans themselves to develop. Marketing is an important factor in the cycle that begins and ends with the needs of consumers. Marketing activities are often misunderstood with sales and promotional activities. Sales and promotion is only one of numerous marketing functions.

Definition of marketing according to world famous Philip Kotler (1996: 6) is as follows:

"marketing is a social and managerial process in which individuals and groups get what they need and want by creating, offering, and exchanging valuable products with others".

Thus, it can be said that the essence of marketing is a process that provides answers to one's needs and wants. Therefore, we can freely state that almost everyone either directly, or indirectly participate in marketing, this is simply because everyone on this planet has desires and needs to be satisfied. 
Many people tend to think about marketing in its narrowest sense, such as covering only sales and advertising. However, marketers define it in a much broader way. William M. Pride and O. C. Farrell stated, for example, the following:

Marketing consists of individual and organizational activities that facilitate and accelerate satisfactory exchange relationships in a dynamic environment through creation, distribution, promotion and pricing of goods, services and ideas.

This view shows the breadth of the problems that the marketing manager must solve, as well as the breadth of information needed to solve these problems. Marketing strategy consists of a mixture of elements traditionally called Marketing Mix. This marketing mix consists of variables that companies can combine to influence the demand for their products.

The elements of marketing mix according to (Philip Kotler, 1994: 98) are: Product, Price, Place, Promotion, also commonly known as 4P:

Product is a combination of "goods and services" offered by a company on a target market.

Price is the amount of money that customers have to pay to get this product.

Place is the activity of the company that makes this product available to target consumers.

Promotion is an activity that communicates information about a service or a product and encourages target customers to buy it.

The theory of marketing states that the key to achieving organizational goals is to be more effective than competitors in integrating marketing activities so that to establish and satisfy the needs and wants at the target market. Wilkinson (1992) argues that the information system is a combination of human and technological facilities as well as tools, media, procedures, and controls so that to organize important communication networks, manage transactions and other routine procedures, assist in management of internal and external users and provide information as the basis for proper decision-making.

From the above definition we can conclude that marketing information system would be most useful for managers and other parties who are in need of a proper basis for decisionmaking. Thus, any marketing concept begins with identification of a target market, focus on customer needs, integration of all activities that will affect the customer directly and so on. At the end of this logical chain, the profit is generated by satisfying the needs of customers. Thus, the main task of any business company when it comes to marketing is to provide satisfaction needed and desired by consumers so that the company's goals are achieved.

Kotler and Armstrong (2003: 152) argue that the marketing information system consists of people, tools, and procedures for collecting, selecting, analyzing, evaluating, and distributing timely and accurate information needed by marketing decision makers.

The job of a marketing manager is to develop strategies and tactics for each element in the marketing mix and then integrate it into a comprehensive marketing plan. Several techniques have been developed to provide the information needed to make product-oriented decisions. The techniques discussed below usually help managers in the course of their decision-making.

The product life cycle provides a framework for all marketing decisions. The product subsystem provides product-related information prior to introduction, during a good sales period, and when it would be appropriate to consider product removal.

Based on the above framework, the hypotheses for further testing can be written as follows: 


\section{OPTIMIZATION OF MARKETING INFORMATION SYSTEM}

$\mathrm{H} 0: \beta \leq 0$, there is no significant influence between marketing information system and product development at one clothing company in Bandung.

$\mathrm{H} 1: \beta>0$, there is a significant influence between marketing information system and product development at one clothing company in Bandung.

\section{Research Methodology}

There are two key variables in this research: the independent variable (free variable) is a variable that affects the dependent variable, in our case this would be marketing information system. Further, this variable will be denoted as (X).

The dependent variable is the variable influenced by the independent variable. In our case this would be product development. This variable is denoted further as (Y).

Population in this research consists of the employees of one clothing company in Bandung, 25 people in total.

The definition of the sample according to (Sugiyono, 2004: 90) suggests: "The sample is part of the number and characteristics possessed by the population". In this research the sampling method used is also according to (Sugiyono, 2004: 107). This is a technique in which we choose all members of the population as our sample. This means that the sample in this study consists of all employees of the clothing company in question.

To test the measuring instrument, the researchers have carried out first the pilot pretest on 30 respondents. The following test results for validity were obtained:

Table 1. KMO and Bartlett Test of Sphericity (calculated by the co-authors)

\begin{tabular}{|c|l|c|}
\hline \multicolumn{2}{|c|}{$\begin{array}{c}\text { Kaiser-Meyer-Olkin Measure of Sampling } \\
\text { Adequacy. }\end{array}$} &, 853 \\
\hline \multirow{2}{*}{$\begin{array}{c}\text { Bartlett's Test of } \\
\text { Sphericity }\end{array}$} & Approx. Chi-Square & 117,388 \\
\cline { 2 - 3 } & Df & 10 \\
\cline { 2 - 3 } & Sig. &, 000 \\
\hline
\end{tabular}

We can see here that the KMO result is 0.853 with the significance of 0.000 . Since the KMO numbers are above 0.5 and the significance is below 0.05 , the factors and the sample should be also analyzed by means of factor analysis.

Sugiyono (2012: 184) stated that an instrument can be treated as reliable when the reliability coefficient of at least 0.6 . is achieved in the course of the reliability test.

Table 2. Reliability test result

(calculated by the co-authors)

\begin{tabular}{|c|c|}
\hline \multicolumn{2}{|c|}{ Reliability Statistics } \\
\hline Cronbach's Alpha & \# of Items \\
\hline, 928 & 5 \\
\hline
\end{tabular}




\section{Discussion}

The data correlation analysis technique selected for this case is Pearson Correlation Analysis. We plan to test the correlation between two variables: marketing information system (X) and product development (Y). Also, the method of successive interval (commonly known as MSI) has been applied in relation to the measurement scale. This correlation works with interval data, and when we got ordinal data - then it was converted into interval one.

Table 3. Regression and Pearson Tests (calculated by the coauthors)

\begin{tabular}{|c|c|c|c|c|c|}
\hline $\mathrm{No}$ & Total X & Total Y & $\mathrm{X} 2$ & $\mathrm{Y} 2$ & $\mathrm{XY}$ \\
\hline 1 & 25.097 & 52.211 & 629.871 & 2725.962 & 1310.346 \\
\hline 2 & 21.168 & 45.378 & 448.084 & 2059.198 & 960.570 \\
\hline 3 & 25.456 & 52.109 & 648.018 & 2715.302 & 1326.486 \\
\hline 4 & 29.185 & 60.337 & 851.765 & 3640.544 & 1760.934 \\
\hline 5 & 24.071 & 51.797 & 579.419 & 2682.928 & 1246.812 \\
\hline 6 & 26.606 & 54.032 & 707.891 & 2919.412 & 1437.576 \\
\hline 7 & 22.441 & 48.458 & 503.585 & 2348.163 & 1087.428 \\
\hline 8 & 22.268 & 42.895 & 495.861 & 1839.993 & 955.186 \\
\hline 9 & 23.445 & 42.365 & 549.654 & 1794.830 & 993.245 \\
\hline 10 & 23.158 & 49.529 & 536.280 & 2453.140 & 1146.983 \\
\hline 11 & 23.686 & 43.050 & 561.050 & 1853.319 & 1019.708 \\
\hline 12 & 23.011 & 52.295 & 529.488 & 2734.749 & 1203.336 \\
\hline 13 & 22.663 & 45.853 & 513.592 & 2102.461 & 1039.137 \\
\hline 14 & 25.055 & 64.191 & 627.737 & 4120.501 & 1608.289 \\
\hline 15 & 18.136 & 47.029 & 328.927 & 2211.687 & 852.927 \\
\hline 16 & 25.194 & 51.987 & 634.752 & 2702.691 & 1309.786 \\
\hline 17 & 25.281 & 49.503 & 639.154 & 2450.578 & 1251.518 \\
\hline 18 & 16.613 & 57.588 & 275.978 & 3316.395 & 956.688 \\
\hline 19 & 29.049 & 57.110 & 843.868 & 3261.567 & 1659.015 \\
\hline 20 & 22.186 & 47.481 & 492.230 & 2254.436 & 1053.423 \\
\hline 21 & 20.525 & 51.368 & 421.272 & 2638.637 & 1054.317 \\
\hline 22 & 27.595 & 67.724 & 761.477 & 4586.492 & 1868.825 \\
\hline 23 & 17.732 & 35.829 & 314.431 & 1283.705 & 635.324 \\
\hline 24 & 16.750 & 31.194 & 280.555 & 973.062 & 522.491 \\
\hline 25 & 19.145 & 44.937 & 366.519 & 2019.294 & 860.296 \\
\hline Total & 575.516 & 1246.249 & 13541.459 & 63689.045 & 29120.646 \\
\hline
\end{tabular}




\section{OPTIMIZATION OF MARKETING INFORMATION SYSTEM}

The Pearson correlation formula (rxy) is as follows:

$$
\operatorname{rxy}=\frac{n\left(\sum x y\right)-\left(\sum x\right)\left(\sum y\right)}{\sqrt{\left\{n \sum x^{2}-\left(\sum x\right)^{2} \int\left(n \sum y^{2}-\left(\sum y\right)^{2}\right\}\right.}},
$$

where:

$\mathrm{n}=$ the number of respondents in the sample,

$\mathrm{X}=$ the value of marketing information system efficiency,

$\mathrm{Y}=$ the value of product development

$$
\begin{array}{lll}
\sum X=575.516 & \sum X^{2}=13541.459 & \sum X Y=29120.646 \\
\sum Y=1246.249 & \sum Y^{2}=63689.045 & n=25
\end{array}
$$

$$
\begin{aligned}
& 25 \times 29120.646-575.516 \times 1246.249 \\
& \operatorname{rxy}=\sqrt{\left\{(25 \times 13541.459)-(575.516)^{2}\right\}\left\{(25 \times 63689.045)-(1246.249)^{2}\right\}} \\
& 728016.139-717236.068 \\
& =\sqrt{\sqrt{(338536.472-331218.696)(1592226.125-1553135.689)}} \\
& =\frac{10780.070}{\sqrt{7317.776 \times 39090.436}} \\
& =\frac{10780.070}{\sqrt{286055069.649}} \\
& =\frac{10780.070}{16913.163}
\end{aligned}
$$

$\operatorname{rxy}=0.637$

We have used SPSS software for calculations of Pearson correlation; details are presented in the following table.

Since our manual calculations and our SPSS results have led us to the same number, we can state that the calculation of correlation has been accurate. The correlation coefficient is equal to 0.637 . To interpret the closeness of influence between the marketing information system and product development the Guildford rule has been used, according to which $\mathrm{r}=$ 0.637 belongs to the strong category.

As it was already mentioned above, in order to prove our hypotheses, we have first calculated the t-test of Student, then its result has been compared with the Student's t-table value with the degree of n-2 and the significance level of alpha. 
Tabel 4. Pearson Correlation (calculated by the coauthors)

\begin{tabular}{|l|c|c|c|}
\hline \multicolumn{2}{|c|}{} & $\begin{array}{c}\text { product } \\
\text { development } \\
(\mathrm{Y})\end{array}$ & $\begin{array}{c}\text { marketing } \\
\text { information } \\
\text { system (X) }\end{array}$ \\
\hline $\begin{array}{l}\text { Pearson } \\
\text { Correlation }\end{array}$ & $\begin{array}{c}\text { product development } \\
(\mathrm{Y})\end{array}$ & 1.000 & .637 \\
\hline Sig. (1-tailed) & $\begin{array}{c}\text { marketing information } \\
\text { system (X) }\end{array}$ & .637 & 1.000 \\
\hline & $\begin{array}{c}\text { product development } \\
(Y)\end{array}$ &. & .000 \\
\hline $\mathrm{N}$ & $\begin{array}{c}\text { product development } \\
\text { system (Y) }\end{array}$ & .000 &. \\
\hline & $\begin{array}{c}\text { marketing information } \\
\text { system(X) }\end{array}$ & 25 & 25 \\
\hline
\end{tabular}

In testing of the hypotheses the following formula has been used:

$$
\begin{gathered}
t_{\text {hitung }}=\frac{b}{S b_{(y)} \quad S b_{(y)}=\sqrt{M S E / S_{x x}}} \\
\text { The results of calculations are as follows: } \\
S_{x x}=\sum x^{2}-\frac{\left(\sum x\right)^{2}}{n}=13541.459-\frac{(575.516)^{2}}{25}=292.711 \\
S_{y y}=\sum y^{2}-\frac{\left(\sum y\right)^{2}}{n}=63689.045-\frac{(1246.249)^{2}}{25}=1563.617 \\
S_{x y}=\sum x y-\frac{\left(\sum x\right)\left(\sum y\right)}{n}=29120.646-\frac{(575.516)(1246.249)}{25}=431.203 \\
S S_{R}=b S_{x y}=1.473 \times 431.203=635.220 \\
S S_{E}=S_{y y}-S S_{R}=1563.617-635.220=928.398 \\
M S_{E}=\frac{S S_{E}}{n-2}=\frac{928.398}{25-2}=37.136 \\
\text { So we found that: } \\
t \text { hitung }=\frac{1.473}{\sqrt{37.136 / 292.711}} \\
=4.136
\end{gathered}
$$

Therefore, we have obtained the t value of 4.136 .

The testing criterion is the limit specified from the value of the table by considering the degrees of freedom $(\mathrm{db})$ and the significance level so that from this limit it can be concluded whether $\mathrm{H} 0$ should be accepted or rejected. The test criteria are as follows: 


\section{OPTIMIZATION OF MARKETING INFORMATION SYSTEM}

Accept hypothesis $\mathrm{H} 0$, if $\mathrm{t}_{\text {calc }} \| \mathrm{t}_{\text {able, }}$

Reject the hypothesis $\mathrm{H} 0$ if $\mathrm{t}_{\text {calc }}>\mathrm{t}_{\text {table. }}$

The $t_{\text {table }}$ value is obtained from the Student t-table, the significance level is $5 \%$ and the degrees of freedom are of $25(n-2)$. From that table we obtain the $t_{\text {table }}$ value of 1.7081 . This value is then compared with the value we have calculated. After calculations according to the above formula, we have obtained the value of 4.136 . This value is greater than the table value so it can be concluded that there is positive and significant influence from the implementation of marketing information system onto product development at one of the clothing companies in Bandung.

Thus, the obtained value from the t-test basically means the rejection of $\mathrm{H} 0$ and the acceptance of H1. So it can be concluded that there is a positive and significant influence from the implementation of marketing information system on product development at the clothing company functioning in Bandung.

Therefore, the results of this hypothesis testing provide empirical evidence proving that the course of product development at the studied clothing company in Bandung is being under the influence of its marketing information system.

\section{Conclusion}

Stemming from the results of this research and finding also support in literature on the same problem, the authors have formulated the following conclusions:

Marketing information system being used by the studied clothing company in Bandung can be described as well-tuned. This has been proved, inter alia, by the results of the Weighted Mean Score analysis (WMS), in which we got $72.89 \%$, this is an ideal score. This means that the marketing information system run by this company has provided information thoroughly for the purposes of operational marketing.

Product development at the same clothing company can be also described as "very good". This is proved by the results of the same Weighted Mean Score analysis (WMS), with its ideal score of $72.21 \%$. It means that product development carried out by this company has run well from the idea and product concept to the stage of commercialization.

The amount of influence from the marketing information system on product development at the company in question reaches $40.6 \%$, while the rest of $59.4 \%$ is influenced by other variables that are not researched here.

The size of the relationship between the marketing information system and product development is 0.637 , and this relationship can be characterized as positive. Judging from the magnitude of variables' correlation coefficients, the marketing information system in question has a strong relationship with the variable of product development.

Thus, we accept the initial hypothesis which states that "marketing information system has a significant influence on product development".

\section{References:}

Arikunto, S. (1998). Research Procedure (Practical Approach). Jakarta : PT.Rineka Cipta. Kotler, P. (2012). Marketing Management. Edisi Millenium Jilid I. Jakarta: PT. Indeks. Lamb, H., Mc. Daniel. (2000). Marketing. Jakarta: PT. Salemba Emban Patria. 
Madiawati, P. N., \& Pradana, M. (2016). Celebrity and halal certificates factors influence on customers' buying interest. Actual problems of economics. (3), 109-116.

Mc. Daniel et al. (2001). Marketing Management. Jakarta: Prenhallindo.

Mc. Leod Raymond, Jr. (2001). Management Information System. Edisi VII Jilid II. Jakarta: Prenhalindo

Natyari, S. G., \& Pradana, M. (2016). Determinants Forming Uber Consumers' Preferences in Bandung City, Indonesia. Safety, 10(6), 7.

Panuju, R. (2000). Business Communication. Jakarta: PT. Gramedia Pustaka Utama.

Saladin, D. (2003). Marketing Essence. Bandung: CV. Linda Karya.

Singarimbun, M., Effendi, S. (1995). Survey Research Method. LP3ES, Lembaga Penelitian, Pendidikan dan Penerangan Ekonomi Sosial.

Sudjana. (1997). Statistic for Economy and Business. Bandung: Tarsito.

Sudjana. (2000). Statistical Method. Bandung: Tarsito.

Sugiyono. (2012). Business Method. Jakarta: Alfabeta.

Swastha, B. (1999). Principles of Marketing. Edisi Ketiga. Yogyakarta: Liberty.

Tjiptono, F. (2001). Marketing Strategy. Edisi Kedua. Yogyakarta: Andi Offset.

Umar, H. (2003). Research Method and Its Application in Marketing. Jakarta: PT. Gramedia Pustaka Utama.

Wardhana, A., \& Pradana, M. (2016). Viral Marketing Determinants of Top Online Shop Brands in Indonesia. Mimbar: Jurnal Sosial dan Pembangunan, 32(1), 25-30.

Wilkinson, J. (1992). Accounting and Information System. Edisi ketiga, Jakarta: Penerbit Binarupa Aksara.

Paper submitted

Paper accepted for publishing

Paper published online
12 January 2018

21 March 2018

15 June 2018 